\title{
PERLINDUNGAN HUKUM TERHADAP KONSUMEN TRANSPORTASI BERBASIS ONLINE YANG MENGGUNAKAN DRIVER CADANGAN
}

\author{
Stefani Erlina Halim \\ (Mahasiswa Program S1 Fakultas Hukum Universitas Tarumanagara) \\ (E-mail: stefanierlina97gmail.com)
}

Siti Nurbaiti

(Corresponding Author)

(Dosen Fakultas Hukum Universitas Tarumanagara. Meraih Gelar Sarjana Hukum di Universitas

Trisakti, Sarjana Sastra jurusan Arkeologi di Universitas Indonesia, Magister Hukum Bisnis di

Fakultas Hukum Universitas Tarumanagara, dan Doktor Ilmu Hukum di Universitas Trisakti)

(E-mail: nurbaiti_05092000@yahoo.com)

\begin{abstract}
Logistic or transportation, including online transportation is an essential aspect in every day's life. Technology advancement has promoted the introduction of online transportation in Indonesia. However, there is no clear integrated regulation of online transportation including reserve driver. This research also to look at how online transportation company will be responsible on the consumer who used the service of 'backup' driver; and what is the legal protection of the consumer in order to protect consumer who had used the service of reserve driver. The method used in this research is normative research specifications, using secondary data and primary data as supporting data with the law approach. The result shows that online transportation customers with reserve driver cannot hold accountability to the online transportation company based on Article 19 of the UUPK and Article 192 UULLAJ, because the business owners are not public transport companies but are the application-based companies. In addition, online transportation also does not provide legal protection to passengers, including of reserve driver, consumers cannot sue the company under UUPK or UULLAJ, but consumers can sue the company under Article 1365 of the Civil Code. Hence, author suggests the government should issue a governmentcontrolled regulation regarding online transportation including reserve driver which could result in the provisions usage of the carrier responsibility in accordance to the UULLAJ by online transportation. Furthermore, online transportation company must provide legal protection to ensure legal certainty for consumers by releasing regulations and sanctions for drivers who lend their account to other driver.
\end{abstract}

Keywords: Consumer Protection, Online Transportation, Reserve Driver 


\section{PENDAHULUAN}

\section{A. Latar Belakang}

Indonesia merupakan salah satu Negara yang mengalami perkembangan yang cukup pesat pada saat ini, tidak hanya di bidang ekonomi tetapi juga pada bidang transportasi dan teknologi. Semakin canggihnya teknologi saat ini sangat memudahkan masyarakat untuk berhubungan. Pada zaman dahulu, masyarakat harus menulis surat dan mengirimnya lewat pos, saat ini masyarakat sangat di mudahkan dengan adanya smartphone atau handphone. Seiring dengan perkembangan teknologi di bidang telekomunikasi, transportasi juga terus berkembang.

Transportasi atau pengangkutan merupakan hal yang sering kita temukan dimana-mana. Seluruh wilayah Indonesia mempunyai transportasi yang dapat menghubungkan wilayah yang satu dengan yang lainnya untuk memperlancar sistem perekonomian dan juga kesatuan dan persatuan bangsa ini. Transportasi merupakan bidang kegiatan yang sangat penting dalam kehidupan masyarakat Indonesia yang disebabkan oleh beberapa faktor antara lain, keadaan geografis Indonesia yang terdiri dari ribuan pulau kecil dan besar, perairan yang terdiri dari sebagian besar laut, sungai dan danau yang memungkinkan pengangkutan dilakukan melalui darat, perairan dan udara guna menjangkau seluruh wilayah Indonesia. ${ }^{1)}$ Adalah penting sekali pengangkutan dalam dunia perniagaan, mengingat sarana ini sebagai angkutan dari produsen ke agen/grosir sampai ke konsumen. $^{2)}$

Pengangkutan juga menunjang pembangunan di berbagai sektor, misalnya sektor perhubungan, pengangkutan memperlancar arus manusia, barang, jasa, informasi ke seluruh penjuru tanah air; sektor pariwisata, pengangkutan memungkinkan para wisatawan menjangkau berbagai objek wisata yang berarti pemasukan devisa bagi Negara; sektor perdagangan,

\footnotetext{
1) Abdulkadir Muhammad, Hukum Pengangkutan Darat, Laut, dan Udara, (Bandung: Citra Aditya Bakti, 2004), hal.7.

2) Sution usman Adji, Djoko Prakoso, dan Hari Pramono, Hukum Pengangkutan Di Indonesia, (Jakarta: Rineka Cipta, 1990), hal.1.
} 
pengangkutan mempercepat penyebaran perdagangan barang kebutuhan sehari-hari dan kebutuhan pembangunan sampai ke seluruh pelosok tanah air; sektor pendidikan, pengangkutan menunjang penyebaran sarana pendidikan dan tenaga kependidikan ke seluruh daerah dan mobilitas penyelenggaraan pendidikan dan demikian juga sektor-sektor lainnya. ${ }^{3)}$ Menyadari begitu pentingnya peran transportasi, maka transportasi perlu untuk ditata dalam suatu sistem transportasi nasional yang terpadu untuk mewujudkan tersedianya jasa transportasi yang aman, nyaman, cepat, teratur, dan dengan biaya yang dapat dijangkau oleh semua lapisan masyarakat.

Ditinjau dari karakteristik jenis penggunaan, moda transportasi orang dapat dibedakan menjadi kendaraan pribadi dan kendaraan umum. Kendaraan pribadi adalah kendaraan yang dioperasionalkan hanya untuk orang yang memiliki kendaraan tersebut. Kendaraan umum adalah kendaraan yang disediakan untuk dipergunakan oleh umum dengan memungut biaya. Kendaraan bermotor umum terdiri atas angkutan orang dengan kendaraan bermotor umum dalam trayek dan angkutan orang dengan kendaraan bermotor umum tidak dalam trayek. Kendaraan umum dapat dikategorikan menjadi kendaraan yang disewakan dan kendaraan umum biasa. Kendaraan umum menawarkan berbagai pilihan jenis transportasi dengan tingkat pelayanan, kenyamanan dan tarif yang berbeda-beda antara jenis transportasi yang satu dengan yang lainnya. Kendaraan angkutan umum terdiri dari kendaraan bermotor dan kendaraan tidak bermotor. Kendaraan bemotor merupakan kendaraan yang digerakkan oleh peralatan mekanik berupa mesin, selain kendaraan yang berjalan di atas rel. ${ }^{4}$ Kendaraan bermotor yang digunakan sebagai angkutan umum meliputi mobil penumpang, mobil bus, mobil barang dan

\footnotetext{
${ }^{3)}$ Abdulkadir Muhammad, Op.Cit., hal.1.

${ }^{4)}$ Indonesia, Undang-Undang Nomor 22 Tahun 2009 tentang Lalu Lintas dan Angkutan Jalan (Lembaran Negara Republik Indonesia Tahun 2009 Nomor 96, Tambahan Lembaran Negara Republik Indonesia Nomor 96, Tambahan Lembaran Negara Republik Indonesia Nomor 5025), Pasal 1 angka 8.
} 
kendaraan khusus. Kendaraan tidak bermotor dibedakan berdasarkan alat penggeraknya yaitu kendaraan yang digerakan oleh tenaga orang seperti becak dan kendaraan yang digerakan oleh tenaga hewan misalnya delman.

Perkembangan transportasi disetiap negara di dunia tentulah berbedabeda, mengikuti kemajuan teknologi di masing-masing Negara. Dengan perkembangan jaman dan juga banyaknya kegiatan masyarakat yang diiringi dengan kemacetan tersebut, masyarakat saat ini cenderung ingin segala sesuatunya yang praktis. Mulai dari makanan, belanja dan juga dengan transportasi. Oleh karena itu, masyarakat di tawarkan dengan suatu layanan transportasi berbasis online yang dapat digunakan hanya dengan mengunduh nya di smartphone. Contoh nya saja seperti Go-jek dan Grab.

Jasa transportasi berbasis online ini disebut juga dengan aplikasi ridesharing yang kemunculannya di Indonesia mulai marak pada tahun 2014. Inovasi transportasi yang demikian merupakan terobosan baru yang bersifat multikreatif, yang tidak hanya menjadi sumbangan bagi perkembangan transportasi nasional, tetapi juga menciptakan lapangan pekerjaan yang sangat signifikan bagi masyarakat Indonesia. ${ }^{5)}$

Mengikuti perkembangan transportasi saat ini, telah berkembang menjadi mata pencaharian yang menjanjikan, dengan bergabung bersama transportasi online maka akan memiliki penghasilan tambahan dan tidak terikat waktu bekerja. Transportasi Online ini tidak hanya sebatas layanan transportasi yang mengantarkan penumpang dari suatu tempat sampai pada tujuannya, tetapi juga tersedia layanan untuk mengantarkan barang, membeli makanan, berbelanja keperluan sehari-hari dengan produk yang berkualitas, top-up pulsa, membeli obat, tiket nonton, sewa mobil untuk berpergian ke banyak tempat dengan driver yang telah disediakan, bahkan layanan untuk kecantikan.

Alasan masyarakat saat ini lebih memilih menggunakan transportasi online seperti Go-jek dan Grab adalah karena persepsi masyarakat yang

$5)$ Andika Wijaya, Aspek Hukum Bisnis Transportasi Jalan Online, (Jakarta: Sinar Grafika, 2016), hal.1. 
menilai bahwa transportasi online lebih praktis dibanding transportasi konvensional, para penggunanya dapat memesan via internet tanpa harus terjun kelapangan untuk mencari transportasi umum, serta tarif yang telah terstandarkan sehingga pelanggan tidak perlu melakukan tawar menawar dengan driver dan juga pada transportasi online tersebut sering di tawarkannya promo-promo yang sangat menarik perhatian masyarakat, sehingga dengan biaya yang relatif murah konsumen dapat sampai pada tujuan.

Kemajuan teknologi yang semakin pesat ini, ternyata pemerintah tidak siap untuk menghadapi perkembangan teknologi yang seperti sekarang ini, hal ini ditunjukkan dengan dikeluarkannya Surat Pemberitahuan Nomor: UM.3012/1/21/Phb/2015 tanggal 9 November 2015 yang dikeluarkan oleh Menteri Perhubungan Republik Indonesia Bapak Ignasius Jonan. ${ }^{6)}$ Namun Surat Pemberitahuan tersebut menuai pro maupun pro kontra yang mengakibatkan terjadinya perdebatan keras maupun bentrokan antar kepentingan transportasi online dan transportasi konvensional.

Pemerintah menerbitkan regulasi terbaru mengenai transportasi online yang menggunakan aplikasi ini untuk menengahi konflik dikalangan masyarakat mengenai transportasi online, yakni Peraturan Menteri Perhubungan No. 32 Tahun 2016 tentang Penyelenggaraan Angkutan Orang Dengan Kendaraan Bermotor Umum Tidak Dalam Trayek (selanjutnya yang disebut Permenhub No. 32 Tahun 2016) yang kemudian dicabut dan diubah dengan Peraturan Menteri Perhubungan No. 26 Tahun 2017 tentang Penyelenggaraan Angkutan Orang dengan Kendaraan Bermotor Umum Tidak dalam Trayek (yang selanjutnya disebut Permenhub No. 26 Tahun 2017) yang kemudian dicabut dan diubah lagi menjadi Peraturan Menteri Perhubungan Nomor 108 Tahun 2017 tentang Penyelenggaraan Angkutan Orang dengan Kendaraan Bermotor Umum Tidak dalam Trayek (yang selanjutnya disebut Permenhub No. 108 Tahun 2017). Tetapi pada tanggal 12 September 2018, beberapa pasal di

\footnotetext{
${ }^{6)}$ Ibid., hal.4.
} 
Permenhub No. 108 Tahun 2017 ini dicabut oleh Mahkamah Agung sesuai dengan Putusan MA Nomor 15P/ HUM/2018 karena ada sejumlah butir pasal yang menurut MA merupakan pemuatan ulang materi norma yang telah dibatalkan oleh Putusan MA Nomor 37/P.HUM/2017 pada tanggal 20 juni $2017^{7)}$ dan saat ini masih dalam tahap revisi.

Transportasi Online tidak hanya memiliki kelebihan-kelebihan tersebut, tetapi juga terdapat banyak kekurangan dari transportasi berbasis online ini, masih sering pengemudi angkutan melakukan tindakan yang dinilai dapat menimbulkan kerugian bagi penumpang, baik itu kerugian yang secara nyata dialami oleh penumpang atau kerugian materiil, maupun kerugian yang secara immateriil seperti kekecewaan dan ketidaknyamanan yang dirasakan oleh penumpang. Pada kenyataannya banyak sekali konsumen yang mengeluhkan dan merasa sangat tidak nyaman dengan driver transportasi online seperti, pengemudi yang berbeda dengan yang terdaftar di aplikasi, juga mobil atau motor dengan nomor polisi kendaraan yang berbeda dengan yang terdaftar di aplikasi. Ini membuktikan bahwa jasa transportasi online ini sering lalai dalam memenuhi hak-hak konsumen. Sering kali konsumen di anggap memiliki suatu kedudukan yang tidak seimbang dengan para pelaku usaha, konsumen tidak berdaya menghadapi posisi yang lebih kuat dari para pelaku usaha. ${ }^{8)}$

Berikut contoh kasus bahwa konsumen menerima pelayanan yang merugikan, yaitu Pada hari Senin, 23 April 2018, seorang yang berinisial SS mengalami peristiwa tidak menyenangkan saat menggunakan jasa transportasi online. Driver Grab Car tersebut adalah Gugus Gunawan yang mengendarai mobil Suzuki Wagon berpelat nomor B 2353 BZB. Menurut keterangannya, setelah ia naik dan grab tersebut jalan, tiba-tiba muncul dua orang dari bangku belakang dan ia disekap oleh orang tersebut.

\footnotetext{
7) Trio Hamdani, "MA Cabut Permen 108, Ini Aturan Taksi Online yang Bakal Hilang", https://finance.detik.com/berita-ekonomi-bisnis/d-4209472/ma-cabut-permen-108-ini-aturan-taksionline-yang-bakal-hilang, diakses tanggal 7 November 2018.

8) Andrian Sutedi, Tanggung Jawab Produk dalam Hukum Perlindungan Konsumen, Cetakan ke-1, (Bogor: Ghalia Indonesia,2008), hal.9.
} 
Peristiwa itu terjadi saat SS hendak berangkat kerja dari kediamannya yang terletak di Duri Selatan 6, Komplek Setia Masa 1, Duri, Tambora, Jakarta Barat sekitar pukul 06.00. Ia memesan Grab Car untuk berangkat kerja ke toko di Tanah Abang, Jakarta Pusat. Ia disekap dalam perjalanan menuju ke tempat kerja oleh dua orang teman driver yang ada di bangku belakang mobil. Tidak hanya disekap, tetapi korban juga ditodong dan diancam dibunuh dengan dimintai barang-barang berharganya. Setelah itu memberikan semua barang berharganya berupa ATM, kalung, gelang dan handphone. Ia mengaku ia mengalami trauma. Ia dibawa berkeliling sekitar tujuh jam oleh pelaku dan ditodong dengan sebuah benda ditubuhnya. Tetapi ia tidak mengetahui rute perjalanannya selama 7 jam itu, karena matanya ditutup, tangan dan kakinya juga diikat, sehingga ia tidak dapat melihat sekitarnya. Sekitar pukul 13.00, SS dikembalikan kerumah oleh driver tersebut. ${ }^{9)}$

Pengguna jasa aplikasi tersebut mengatakan ia telah telah mengadukan kejadian ini kepada pihak Grab dan Polisi. Setelah diselidiki ternyata yang mengemudikan transportasi online saat itu bukanlah Gugus Gunawan melainkan sedang di pakai oleh anak tirinya.

Berdasarkan uraian yang telah dikemukakan tersebut telah terjadi suatu tindakan curang yang menimbulkan kerugian pada pengguna aplikasi transportasi online ini. Berdasarkan fakta hukum yang dijabarkan tersebut, maka penulis mengangkat penulisan ini dengan judul: "Perlindungan Hukum Terhadap Konsumen Transportasi Berbasis Online Yang Menggunakan Driver Cadangan"

\section{B. Perumusan Masalah}

Berdasarkan latar belakang yang diuraikan tersebut, permasalahan yang hendak diteliti dalam penulisan ini yaitu:

\footnotetext{
9) Rima Wahyunigrum, "Kronologi Penyekapan Penumpang oleh Sopir Grab Car di Tambora”, https://megapolitan.kompas.com/read/2018/04/25/17303401/kronologi-penyekapanpenumpang-oleh-sopir-grab-car-di-tambora, diakses tanggal 27 Juli 2018.
} 
1. Bagaimana tanggung jawab perusahaan transportasi berbasis online terhadap konsumen yang menggunakan driver cadangan?;

2. Bagaimana perlindungan hukum terhadap konsumen pengguna jasa transportasi berbasis online yang menggunakan driver cadangan?

\section{PEMBAHASAN}

1. Tanggung Jawab Transportasi berbasis Online terhadap Konsumen yang Menggunakan Driver Cadangan

Suatu pengangkutan didasarkan pada suatu perjanjian yang mana harus memenuhi Pasal 1320 KUHPerdata yaitu bahwa suatu perjanjian dikatakan sah jika terpenuhi 4 (empat) syarat yaitu: kata sepakat dari mereka yang mengikatkan dirinya; kecakapan untuk membuat suatu perikatan; suatu hal yang tertentu dan sebab yang halal. Jika dikaitkan dengan UULLAJ, penjelasan Pasal 1 angka 10 ditegaskan yang termasuk dalam pengertian kendaraan bermotor umum yaitu kendaraan bermotor yang disewakan kepada orang lain baik dengan maupun tanpa pengemudi, selama jangka waktu tertentu, Pasal 138 Ayat (3) UULLAJ, mengatakan bahwa angkutan umum orang dan/atau barang hanya dilakukan dengan kendaraan bermotor umum, maka dalam transportasi online tidak memenuhi empat syarat tersebut, bahwa syarat subjektif nya sudah terpenuhi, dimana ada kata sepakat dari konsumen dan pelaku usaha, antara konsumen dan pelaku usaha pun adalah cakap sehingga dapat melakukan perikatan, tetapi tidak memenuhi syarat objektifnya karena transportasi online bukan sebagai angkutan umum dan juga tidak memiliki izin operasional, transportasi online pada umumnya menggunakan kendaraan milik pribadi dari pengemudi yang berarti tetap menggunakan plat hitam dan bukan plat kuning walaupun sudah berbadan hukum, dan juga kendaraan milik pribadi dari pengemudi yang berarti tetap menggunakan plat hitam dan bukan plat kuning walaupun sudah berbadan hukum. 
Pasal 139 Ayat (4) UULLAJ disebutkan jika penyediaan jasa angkutan umum dilaksanakan oleh Badan Usaha Milik Negara, Badan Usaha Milik Daerah dan/atau badan hukum lain sesuai dengan ketentuan yang berlaku. Pasal 37 Ayat (1) Permenhub N0. 108 Tahun 2017, juga dikatakan bahwa perusahaan angkutan umum sebagaimana dimaksud dalam pasal 36 Ayat (1), harus berbentuk badan hukum Indonesia sesuai dengan ketentuan peraturan perundang-undangan. Dalam Pasal 39 Ayat (3) Peraturan Kepala Kepolisian Republik Indonesia Nomor 5 tahun 2012 mengatur bahwa tanda nomor kendaraan bermotor umum adalah dasar berwarna kuning, dengan tulisan berwarna hitam.

Transportasi online saat ini sudah berbadan hukum dalam hal ini mengenai Grab yaitu berada dibawah naungan PT Solusi Transportasi Indonesia dan berkerjasama dengan Induk Koperasi Kepolisian Republik Indonesia koperasi yang bernama INKOPPOL, tetapi sebenarnya yang berbadan hukum disini adalah perusahaan aplikasinya yaitu Grab karena pihak Grab tidak mengakui dirinya sebagai perusahaan pengangkutan dan bukan angkutannya yang berbadan hukum, jadi transportasi online masih belum sesuai dengan UULLAJ karena transportasi tersebut masih menggunakan kendaraan pribadi yang berplat hitam, dimana hal tersebut melanggar ketentuan peraturan yang ada, karena sesuai dengan pendapat Dr. Amad Sudiro, S.H., M.H., M.M., bahwa kendaraan plat hitam adalah kendaraan pribadi yang seharusnya tidak boleh digunakan untuk mengangkut penumpang yang berbayar.

Pasal 1313 KUHPerdata, juga menentukan bahwa perjanjian adalah suatu perbuatan dengan mana satu orang atau lebih mengikat dirinya terhadap satu orang atau lebih. Perjanjian pada transportasi online ini terletak pada saat penumpang memesan transportasi online dimana pelaku usaha berjanji akan mengantarkan konsumen selamat sampai ke tempat yang dituju sedangkan konsumen berjanji akan membayar sesuai dengan nilai yang telah diperjanjikan. Masing-masing pihak ini memiliki tanggung jawab dalam hal pengangkutan. 
Pengemudi yang tidak sesuai dengan yang terdaftar di aplikasi atau yang biasa dikenal dengan driver cadangan adalah tidak diperbolehkan, karena membahayakan keamanan, kenyamanan dan keselematan dari penumpang, pengemudi yang tidak sesuai dengan yang terdaftar di aplikasi juga melanggar ketentuan kode etik pengemudi Grab Car. Hal tersebut dapat menimbulkan kerugian bagi konsumen. Pada Pasal 1365 KUHPerdata, yang lazim dikenal sebagai pasal tentang perbuatan melawan hukum, mengharuskan terpenuhinya 4 (empat) unsur pokok, yaitu:

1. Adanya perbuatan;

2. Adanya unsur kesalahan;

3. Adanya kerugian yang diderita;

4. Adanya hubungan kausalitas antara kesalahan dan kerugian.

Jika dikaitkan dengan kasus pengemudi yang tidak sesuai dengan yang terdaftar di aplikasi, maka telah memenuhi 4 (empat) unsur pokok perbuatan melawan hukum, dimana dijelaskan bahwa tiba-tiba penumpang ditodong, diancam akan dibunuh dan dimintai barang-barang berharganya dan juga penumpang hampir diperkosa, hal tersebut menyebabkan trauma yang sangat mendalam bagi penumpang tersebut. Terpenuhinya unsur perbuatan yaitu perbuatan penggantian pengemudi transportasi online, dan juga sudah jelas adanya unsur kesalahan karena melanggara kode etik pengemudi Grab Car, konsumen juga mengalami kerugian yaitu kerugian berupa materil ataupun non materil, dan terdapatnya hubungan kausalitas antara kesalahan dan kerugian.

Pasal 27 Ayat (1) huruf d Permenhub No 108 Tahun 2017, Kendaraan yang dipergunakan untuk pelayanan Angkutan sewa khusus sebagaimana dimaksud dalam Pasal 26 ayat (1), wajib memenuhi persyaratan sebagai berikut, dilengkapi dengan tanda khusus berupa stiker yang ditempatkan di kaca depan kanan atas dan belakang dengan memuat informasi wilayah operasi, tahun penerbitan kartu pengawasan, nama badan hukum, dan latar belakang logo Perhubungan. Pada saat ini juga belum ditemukan adanya 
tanda khusus sesuai yang tertera dalam pasal tersebut. Padahal jika syarat tersebut sudah terpenuhi maka dapat mengurangi adanya kendaraan yang berbeda dengan yang tertera diaplikasi dan mengurangi adanya ancamanancaman bahaya dari pengemudi. Walaupun kemungkinan beberapa pasal dalam permenhub ini akan dicabut, tetapi karena belum dibuat aturan yang baru, maka permenhub ini akan tetap digunakan dalam penulisan ini.

Tanggung jawab di atur pada Pasal 19 Ayat (1) UUPK yang mengatakan bahwa pelaku usaha bertanggung jawab memberikan ganti rugi atas kerusakan, pencemaran dan/atau kerugian konsumen akibat mengkonsumsi barang dan/atau jasa yang dihasilkan atau diperdagangkan dan sesuai dengan Pasal 19 Ayat (4) UUPK, pemberian ganti rugi tidak menghapuskan kemungkinan adanya tuntutan pidana berdasarkan pembuktian lebih lanjut mengenai adanya unsur kesalahan, dengan demikian, tanggung jawab pelaku usaha terbagi menjadi 2 (dua) aspek yaitu aspek perdata (hukum privat) dan aspek pidana (hukum publik) jo Pasal 192 Ayat (1) UULLAJ, perusahaan angkutan umum bertanggung jawab atas kerugian yang diderita oleh penumpang yang meninggal dunia atau luka akibat penyelenggaraan angkutan, kecuali disebabkan oleh suatu kejadian yang tidak dapat dicegah atau dihindari atau karena kesalahan penumpang.

Berdasarkan dari 5 (lima) prinsip tanggung jawab dalam hukum yang telah disebutkan, maka penulis berpendapat bahwa dalam transportasi online terkait kasus driver cadangan, menggunakan prinsip tanggung jawab berdasarkan atas kesalahan atau Based on Fault, oleh karena yang seharusnya berusaha untuk membuktikan kebenarannya adalah pihak pengangkut, tetapi dalam transportasi online, konsumen sebagai penumpanglah yang berusaha untuk membuktikan kesalahan dari pihak pengangkut.

Transportasi yang dijadikan sebagai angkutan umum merupakan transportasi yang diatur dalam undang-undang (yang selanjutnya disebut UU). Pengaturan tentang transportasi ataupun angkutan umum tersebut 
diatur di dalam UULLAJ. Dalam Pasal 1 angka 3 UULLAJ menyatakan bahwa angkutan adalah perpindahan orang dan/atau barang dari suatu tempat ke tempat lain dengan menggunakan kendaraan di ruang lalu lintas jalan dan Menurut H.M.N. Purwosutjipto, pengangkutan adalah perjanjian timbal balik antara pengangkut dan pengirim, dimana pengangkut mengikatkan diri untuk menyelenggarakan pengangkutan barang dan/ atau orang dari suatu tempat ke tempat tertentu dengan selamat, sedangkan pengirim mengikatkan diri untuk membayar uang angkutan.

Menurut Dr. Amad Sudiro, S.H., M.H., M.M, dosen Fakultas Hukum Universitas Tarumanagara, menyatakan bahwa terkait dengan tanggung jawab, jika dilihat dari UUPK berbeda dengan yang ada di UULLAJ. Di dalam UULLAJ, mengatur transportasi yang termasuk dalam kategori transportasi umum yang proses perizinannya jelas, sedangkan transportasi online bukan termasuk dalam jenis kategori umum dan perizinannya juga belum terlalu jelas. Dalam hal ini, terdapat tanggung jawab privat dan tanggung jawab publik. Dalam permasalahan yang sedang dibahas ini termasuk dalam tanggung jawab privat terhadap kerugian yang dialami konsumen pengguna jasa transportasi online dengan driver cadangan.

Saya setuju dengan pendapat beliau, mengenai driver cadangan, beliau mengatakan bahwa salah satu kelemahan operasional grab adalah dari proses perizinan, masalah transportasi umum berbeda dengan transportasi pada umumnya. Transportasi umum sudah jelas dan sudah di atur bagaimana proses perizinan untuk mengangkut muatan penumpang, baik melalui moda darat maupun moda lainnya. Dari segi tanggung jawab yang diberikan oleh transportasi online, struktur hubungan hukumnya sedikit berbeda, karena siapapun dapat mendaftar dan tidak ada perjanjian yang jelas, sering dipertanyakan apabila ada pengguna jasa transportasi online yang mengalami kerugian siapa yang harus bertanggung jawab, sehingga terjadi lempar tanggung jawab antara pengemudi dengan perusahaan aplikasi tersebut. Saat ini, belum ada peraturan yang jelas yang mengatur mengenai transportasi online termasuk juga mengenai driver 
cadangan. Saya juga setuju dengan pendapat beliau bahwa dari sisi yuridis formal pihak transportasi online tidak memenuhi syarat sebagai transportasi pada umumnya.

Menurut Bapak Bambang Sumantri, M.B.A., Komisioner BPKN, beliau menyebutkan mengenai driver cadangan, harus adanya edukasi kepada konsumen yang mengajarkan mengenai adanya hak-hak konsumen yang tercantum dalam Pasal 4 UUPK dan klausula baku dan juga jika plat nomor berbeda ataupun supir berbeda dengan yang terdaftar di aplikasi maka lebih baik di tolak dan beritahu kepada sistem Grab tersebut demi keamanan konsumen. Dengan menggunakan driver cadangan berarti sudah melanggar hak dari konsumen. Karena bukan hak pengemudi tersebut untuk mengemudikan mobil/motor yang terdaftar di aplikasi tersebut. Dan juga pemerintah harus mengatur lebih lanjut mengenai hubungan kerja antara Grab dan Pengemudi, dan mana pihak yang merupakan pengangkut agar tidak terjadi lagi lempar tanggung jawab jika adanya kerugian.

Berdasarkan analisa penulis, harus diatur lebih dahulu mengenai kejelasan hubungan antara perusahaan transportasi online dengan pengemudinya, juga antara perusahaan transportasi online dengan penumpang. Dengan adanya peraturan tersebut maka tanggung jawab dapat terealisasikan dengan baik dan tidak adanya lagi saling lempar tanggung jawab. Sebagai suatu perusahaan transportasi maka perusahaan tersebut wajib untuk turut bertanggung jawab atas kerugian yang diderita konsumen.

Hubungan kerjasama pasti dilandasi oleh suatu perjanjian kerjasama secara tertulis yang disetujui oleh kedua belah pihak, tetapi antara Grab dengan pengemudi tidak terdapat perjanjian kerjasama tersebut. Tidak adanya perjanjian kerjasama antara perusahaan transportasi online dengan pengemudi juga menjadi salah satu alasan ke abu-abuan tanggung jawab transportasi online.

Dalam kasus transportasi online tersebut, konsumen yang menggunakan transportasi online dengan driver cadangan tidak dapat 
meminta pertanggung jawaban kepada perusahaan transportasi berbasis online berdasarkan ketentuan yang terdapat didalam Pasal 19 UUPK dan Pasal 192 UULLAJ, karena pelaku usahanya bukanlah perusahaan angkutan umum, melainkan perusahaan berbasis aplikasi dan transportasi online ini juga tidak memenuhi syarat sebagai angkutan umum sebagaimana yang dicantumkan dalam Pasal 139 Ayat (4) UULLAJ dimana dalam transportasi online, yang berbadan hukum adalah perusahaan aplikasi dan bukan angkutan umumnya.

\section{Perlindungan Hukum terhadap Konsumen Pengguna Jasa}

\section{Transportasi berbasis Online yang Menggunakan Driver Cadangan}

Berdasarkan latar belakang yang telah dibahas sebelumnya, diketahui bahwa kurangnya payung hukum yang mengatur mengenai transportasi online menjadi salah satu permasalahan bagi konsumen dalam menggunakan jasa transportasi tersebut. Tentunya hal ini bertentangan dengan UUPK dan UULLAJ.

Transportasi yang dijadikan sebagai angkutan umum merupakan transportasi yang diatur dalam undang-undang. Pengaturan tentang transportasi ataupun angkutan umum tersebut diatur di dalam UULLAJ. Dalam Pasal 1 angka 3 UULLAJ menyatakan bahwa angkutan adalah perpindahan orang dan/atau barang dari suatu tempat ke tempat lain dengan menggunakan kendaraan di ruang lalu lintas jalan dan Menurut H.M.N. Purwosutjipto, pengangkutan adalah perjanjian timbal balik antara pengangkut dan pengirim, dimana pengangkut mengikatkan diri untuk menyelenggarakan pengangkutan barang dan/ atau orang dari suatu tempat ke tempat tertentu dengan selamat, sedangkan pengirim mengikatkan diri untuk membayar uang angkutan.

Menurut Dr. Amad Sudiro, S.H., M.H., M.M, dosen Fakultas Hukum Universitas Tarumanagara, menyatakan bahwa transportasi online jika dilihat dari sisi yuridis formal mereka tidak memenuhi syarat sebagai transportasi pada umumnya. Bahwa antara pengemudi dengan perusahaan 
transportasi online harus memiliki bentuk perjanjian yang jelas dalam menjalankan usahanya. Penulis setuju dengan pendapat beliau tersebut karena dengan tidak adanya kejelasan tersebut sehingga hak-hak konsumen sering dirugikan. Juga dibutuhkannya payung hukum yang jelas yang mengatur mengenai transportasi online ini untuk semakin meningkatkan perlindungan terhadap konsumen. Masyarakat yang mengalami tindakan yang merugikan konsumen tersebut dapat menggugat di pengadilan atau juga dapat melalui BPSK. Pelaporan dapat dilakukan melalui publikasi pada media-media internet, seperti artikel dan petisi online dilengkapi dengan bukti-bukti yang jelas. Konsumen harus lebih cermat dan aktif dalam memilih penyedia jasa layanan transportasi online, sedangkan pelaku usaha harus meningkatkan pelayanannya kepada konsumen dikarenakan banyaknya pesaing-pesaing lain sehingga konsumen dapat meninggalkan dengan beralih menggunakan jasa layanan transportasi umum ataupun transportasi online yang lain.

Menurut Bapak Bambang Sumantri, M.B.A., Komisioner BPKN, Perlindungan Konsumen adalah segala upaya yang dilakukan untuk melindungi konsumen. Beliau menyebutkan mengenai driver cadangan untuk harus adanya edukasi kepada konsumen yang mengajarkan mengenai adanya hak-hak konsumen yang tercantum dalam Pasal 4 UUPK dan klausula baku dan juga jika plat nomor berbeda ataupun supir berbeda dengan yang terdaftar di aplikasi maka lebih baik di tolak dan beritahu kepada sistem Grab tersebut demi keamanan konsumen.

Perlindungan hukum dari Grab sendiri sebenarnya masih kurang, seharusnya pihak Grab harus memeriksa terlebih dahulu mobil/motor yang didaftarkan, tidak dengan mudah menerimanya begitu saja. Beliau menganjurkan seharusnya penumpang dari transportasi online ini di asuransikan melalui penambahan tarif yang ditentukan. Sehingga tidak terjadi lagi lempar tanggung jawab.

Terdapat 2 (dua) subjek hukum dalam perlindungan konsumen yaitu pelaku usaha dan konsumen. Konsumen adalah setiap orang yang membeli 
suatu barang dan/atau jasa untuk dipakai dan dinikmati oleh dirinya sendiri, orang lain, maupun makhluk hidup lainnya dan barang dan/atau jasa tersebut tidak untuk dijual kembali. Sedangkan, pelaku usaha adalah orang perseorangan atau badan usaha, yang baik berbentuk badan hukum maupun bukan badan hukum yang berkedudukan atau melakukan kegiatan dalam wilayah hukum negara Republik Indonesia, yang menyelenggarakan kegiatan usaha dalam bidang ekonomi. Dalam bidang transportasi, yang disebut sebagai konsumen adalah penumpang yang menggunakan jasa transportasi tersebut sedangkan pelaku usaha adalah pengangkut atau penyedia jasa dari transportasi tersebut.

Konsumen dan pelaku usaha memiliki hak dan kewajiban masingmasing sebagaimana yang telah diatur didalam Pasal 4 dan Pasal 5 UUPK. Pada Pasal 4 UUPK khususnya pada angka 1 menyatakan bahwa adanya hak atas kenyamanan, keamanan dan keselamatan dalam mengkonsumsi barang dan jasa. Hak ini merupakan salah satu hak yang sangat penting. Maksud dari hak ini adalah bahwa seorang konsumen yang menggunakan jasa transportasi tersebut harus di antar dengan nyaman, aman dan selamat sampai pada tujuan.

Hak berikutnya pada angka 3 menyatakan adanya hak atas informasi yang benar, jelas dan jujur mengenai kondisi serta jaminan yang dijanjikan. Yang dimaksud dengan hak ini adalah bahwa konsumen memilik hak untuk mendapatkan suatu keterangan atau informasi yang sesuai dengan barang atau jasa yang dikonsumsi, agar konsumen mendapatkan suatu kejelasan yang dapat menghidarinya dari kerugian. Jika dikaitkan dengan hak atas kenyamanan, keamanan dan keselamatan dalam mengkonsumsi jasa, maka setiap jasa transportasi online yang mempunyai risiko terhadap keamanan konsumen, harus disertai dengan informasi yang benar, jelas dan jujur sesuai dengan yang tertera di aplikasi

Hak selanjutnya pada angka 4 adalah hak untuk didengar pendapat dan keluhannya atas barang dan/atau jasa yang digunakan. Maksud dari hak ini adalah konsumen harus didengar pendapatnya agar barang dan/atau 
jasa tersebut bisa dapat menjadi barang dan/atau jasa yang lebih baik serta harus mendengarkan keluhan konsumen karena konsumen merupakan orang yang menggunakan barang dan/atau jasa tersebut, apakah barang dan/atau jasa tersebut melanggar suatu ketentuan yang seharusnya.

Dalam menggunakan jasa transportasi online, pelaku usaha harus memperhatikan hak-hak daripada konsumen. Dalam kasus menggunakan pengemudi yang berbeda dengan yang terdaftar di aplikasi atau driver cadagan sudah jelas bahwa hak atas informasi yang benar, jelas dan jujur mengenai kondisi serta jaminan yang dijanjikan tidak terpenuhi. Karena terdapat ketidaksesuaian antara pengemudi yang terdaftar di aplikasi dengan pengemudi yang mengangkut konsumen tersebut. Apalagi hingga menyebabkan suatu kerugian pada konsumen, yang berarti bahwa hak atas kenyamanan, keamanan dan keselamatan dalam mengkonsumsi barang dan jasa juga tidak terpenuhi. Pada kasus ini, adanya kenyamanan yang dilanggar karena konsumen tidak merasa nyaman saat menggunakan jasa transportasi online tersebut, juga keamanan, bahwa konsumen pada saat menggunakan menggunakan jasa transportasi tersebut ia tidak di antar sampai pada tujuan melainkan di ikat dan dimintai barang-barang berharganya. Konsumen memiliki hak untuk memperoleh kenikmatan atas barang dan/atau jasa yang diperdagangkan oleh pelaku usaha. Bentuk kenikmatan atas konsumsi barang dan/atau jasa oleh konsumen adalah rasa aman dan rasa selamat.

Setelah konsumen mendapatkan hak-haknya, konsumen juga harus melaksanakan kewajibannya. Pasal 5 angka 3 UUPK, menyebutkan konsumen wajib untuk membayar sesuai dengan nilai tukar yang disepakati. Maksudnya adalah konsumen yang telah di antar sampai pada tujuan dengan selamat harus membayar sesuai dengan nilai yang sudah disepakati pada awal perjanjian.

Disamping hak-hak dan kewajiban dari konsumen, pelaku usaha juga mempunyai hak-hak dan kewajiban yang harus dihormati. Hak pelaku usaha pada angka 1 adalah hak untuk menerima pembayaran yang sesuai 
dengan kesepakatan mengenai kondisi dan nilai tukar barang dan/atau jasa yang diperdagangkan. Maksudnya adalah sama seperti kewajiban konsumen untuk membayar sesuai dengan nilai yang telah disepakati.

Kewajiban daripada pelaku usaha Pasal 7 UUPK, khususnya pada angka 1 yang menyatakan untuk beritikad baik dalam melakukan kegiatan usahanya. Juga pada angka 2 yaitu memberikan informasi yang benar, jelas dan jujur mengenai kondisi dan jaminan barang dan/atau jasa serta memberi penjelasan penggunaan, perbaikan dan pemeliharaan, dan angka 3 yaitu memperlakukan atau melayani konsumen secara benar dan jujur serta tidak diskriminatif, yang berarti pelaku usaha dilarang membedakan konsumen dalam memberikan pelayanan dan dilarang membedakan mutu pelayanan kepada konsumen. Jika dilihat pada kasus driver cadangan maka ketiga kewajiban tersebut tidak dipenuhi oleh pelaku usaha.

Pihak Grab harus memperhatikan hak-hak dari konsumen dalam menjalankan usahanya, salah satu hak konsumen yang harus diperhatikan dalam transportasi online sesuai dengan pencetus hak-hak konsumen pertama kali yaitu Presiden Amerika Serikat John F. Kennedy adalah The right to be informed about product. Jika dilihat pada kasus driver cadangan, maka adanya ketidaksesuaian informasi mengenai driver yang mengemudi dan driver yang tertera pada aplikasi.

Hubungan hukum antara pelaku usaha dan konsumen dalam transportasi online ini juga mengacu pada asas-asas perlindungan konsumen. Salah satu asas perlindungan konsumen yaitu asas kepastian hukum, yang dimaksud dengan asas ini agar baik pelaku usaha maupun konsumen menaati hukum dan memperoleh keadilan dalam penyelenggaraan perlindungan konsumen, serta Negara menjamin kepastian hukum. Sesuai dengan asas tersebut, baik hak-hak pelaku usaha maupun hak-hak konsumen dilindungi oleh peraturan perundangundangan dan sebaliknya masing-masing pelaku usaha dan konsumen memiliki kewajiban yang harus dilaksanakan sesuai dengan peraturan perundang-undangan yang berlaku. 
Selain asas kepastian hukum, juga terdapat asas keamanan dan keselamatan konsumen. Asas ini dimaksudkan untuk memberikan jaminan atas keamanan dan keselamatan kepada konsumen dalam penggunaan, pemakaian, serta pemanfaatan barang dan/atau jasa yang dikonsumsi atau digunakan. Asas ini dimaksudkan supaya konsumen mendapatkan jaminan atas manfaat yang akan diperoleh dari jasa itu, sebaliknya jasa itu juga harus diberikan jaminan bahwa apabila konsumen menggunakan sesuai dengan apa yang tercantum dalam perjanjian tersebut, maka konsumen akan dijamin keamanan dan keselamatannya dari efek negatif yang ditimbulkan oleh pemakaian jasa tersebut. Tetapi dalam transportasi online tidak terpenuhi asas tersebut, karena perlindungan hukum yang kurang sehingga tidak adanya kepastian hukum dan keamanan dan keselamatan dari konsumen pun lemah.

Konsumen sebagai pihak yang lemah tentu harus mendapatkan perlindungan hukum dari pemerintah. Pemerintah harus turun tangan dalam melindungi konsumen dari pelaku usaha yang nakal. Bentuk perlindungan hukum terbagi 2 yaitu perlindungan hukum preventif dan perlindungan hukum represif. Bentuk perlindungan yang diterima oleh konsumen yaitu berupa perlindungan yang bersifat preventif yaitu perlindungan yang diberikan oleh pemerintah dengan tujuan untuk mencegah sebelum terjadinya pelanggaran. Sesuai dengan pendapat Ketua MPR bahwa untuk mengatasi persoalan tersebut, maka Negara harus hadir yaitu dengan harus adanya peraturan yang memayungi. Jika Negara turut campur tangan maka persoalan transportasi online ini akan pelan-pelan teratasi.

Pada poin ke 2 kode etik pengemudi grab car tertulis untuk menyedikan transportasi yang aman pada konsumen, keselamatan pelanggan dan pengemudi dalam program Grab Car adalah perhatian yang paling utama. Pada poin ke 2 tersebut juga tertulis salah satunya bahwa adalah kewajiban pengemudi untuk mengangkut penumpang dengan aman sejalan dengan peraturan mengenai jalan dikota tempat pengemudi berada. 
Pihak Grab merekomendasikan bahwa pengemudi selalu mengingatkan penumpang untuk menggunakan sabuk pengaman ketika berada dalam kendaraan.

Pada poin ke 3 juga tertulis untuk menghindari kekerasan dan perilaku agresif, dengan keamanan dan keselamatan sebagai pilar kuncinya, Grab Car tidak membenarkan bentuk kekerasan atau agresi apapun. Adalah hal yang sangat dilarang untuk melakukan bentuk apapun atas kekerasan seksual, termasuk membuat komentar/ tulisan cabul, pelecehan seksual, kontak fisik yang tidak diinginkan, pengekangan yang tidak sesuai dengan hukum, membius, penganiayaan dan pemerkosaan. Semua hal tersebut melanggar hukum dan merupakan suatu pelanggaran serius terhadap kebijakan keselamatan Grab. Pelaku akan dituntut menurut hukum.

Pada poin ke 5 juga tertulis untuk menyediakan transportasi yang dapat diandalkan kepada pelanggan. Untuk membangun Grab Car sebagai suatu program pemesanan yang dapat diandalkan. Pada poin ke 5 tersebut juga terdapat persyaratan terhadap pengemudi Grab Car, bahwa pengemudi tidak boleh memindahkan suatu pekerjaan pada pengemudi lain. Bahwa pengemudi yang menjemput dan mengantar penumpang harus sesuai dengan pengemudi yang tertera dan terdaftar di aplikasi tersebut.

Berdasarkan analisis, maka dapat dilihat bahwa transportasi online atau Grab tidak sesuai dengan transportasi umum yang diatur dalam UULLAJ. Grab tidak menggunakan plat kuning seperti kendaraan umum lainnya. Grab tetap menggunakan plat hitam sedangkan menurut Dr. Amad Sudiro, S.H., M.H., M.M., dalam UULLAJ plat hitam tidak boleh digunakan sebagai angkutan umum berbayar.

Perlindungan hukum terhadap konsumen transportasi online ini juga masih sangat rendah karena longgarnya peraturan yang mengatur dan juga rendahnya pengetahuan masyarakat mengenai hak-hak konsumen tersebut, juga tidak adanya aturan yang mengatur mengenai ganti rugi. Sehingga kadang pelaku usaha dapat beritikad tidak baik dalam menjalankan usahanya. 
Hubungan kerjasama antara perusahaan transportasi online dengan pengemudi tidak terdapat perjanjian kerjasama, kedua pihak ini hanya diikat melalui kode etik pengemudi Grab Car, sedangkan kode etik tersebut bukanlah suatu aturan hukum yang tegas, dimana dalam kode etik tersebut tidak diatur mengenai hak dan kewajiban dari masing-masing pihak. Sehingga walaupun pada poin ke 5 sudah diatur bahwa pengemudi tidak boleh memindahkan suatu pekerjaan pada pengemudi lain, tetapi masih ada saja pengemudi yang melakukan hal tersebut, karena tidak adanya sanksi yang tegas yang mengaturnya.

Kasus transportasi online yang menggunakan driver cadangan, didalamnya tidak terdapat adanya perlindungan hukum bagi konsumen transportasi online yang menggunakan driver cadangan karena hukum yang tidak mendukung, kurangnya payung hukum mengenai transportasi online ini menjadi persoalan utama lemahnya perlindungan hukum bagi penumpangnya, sesuai dengan pendapat Bapak Bambang Sumantri, M.B.A., dan transportasi online bukanlah termasuk dalam jenis angkutan umum sesuai yang diatur dalam UULLAJ. Di zaman seperti sekarang ini, transportasi online memang sangat dibutuhkan oleh masyarakat, selain memberikan kemudahan untuk berpergian, harganya juga terbilang relatif murah, tetapi jika peraturan hukumnya juga tidak kunjung diperbaiki maka akan semakin membahayakan konsumennya, hak-hak konsumen tidak dapat terpenuhi dan penumpang transportasi online termasuk yang menggunakan driver cadangan tidak dapat menuntut berdasarkan UUPK maupun UULLAJ, tetapi penumpang hanya dapat menuntut berdasarkan Pasal 1365 KUHPerdata.

\section{PENUTUP}

\section{A. Kesimpulan}

1. Konsumen yang menggunakan transportasi online dengan driver cadangan tidak dapat dimintakan tanggung jawab kepada perusahaan transportasi berbasis online berdasarkan ketentuan yang terdapat 
didalam Pasal 19 UUPK dan Pasal 192 UULLAJ, karena pelaku usahanya bukanlah perusahaan angkutan umum, melainkan perusahaan berbasis aplikasi dan transportasi online ini juga tidak memenuhi syarat sebagai angkutan umum sebagaimana yang dicantumkan dalam Pasal 139 Ayat (4) UULLAJ dimana dalam transportasi online, yang berbadan hukum adalah perusahaan aplikasi dan bukan angkutan umumnya.

2. Transportasi online tidak memberikan perlindungan hukum kepada penumpangnya, aturan yang mengatur tidak dapat dipergunakan karena transportasi online bukanlah termasuk dalam jenis angkutan umum sesuai yang diatur dalam UULLAJ. Penumpang transportasi online termasuk yang menggunakan driver cadangan tidak dapat menuntut berdasarkan UUPK maupun UULLAJ, tetapi penumpang hanya dapat menuntut berdasarkan Pasal 1365 KUHPerdata.

\section{B. Saran}

1. Sebaiknya pemerintah mengeluarkan peraturan yang resmi mengenai transportasi online termasuk mengenai driver cadangan sehingga transportasi online dapat mempergunakan ketentuan tanggung jawab pengangkut yang terdapat didalam UULLAJ;

2. Perusahaan transportasi online harus memberikan perlindungan hukum untuk menjamin kepastian hukum terhadap konsumennya dengan membuat peraturan transportasi online termasuk mengenai driver cadangan serta sanksi yang tegas kepada pengemudi yang meminjamkan aplikasinya kepada pengemudi lain, sehingga tidak ditemukan lagi adanya driver cadangan. 


\section{DAFTAR PUSTAKA}

\section{A. Buku}

Adji, Sution Usman. et al. Hukum Pengangkutan Di Indonesia. (Jakarta: Rineka Cipta, 1990).

Amiruddin dan H. Zainal Asikin. Pengantar Metode Penelitian Hukum. Cetakan ke-1. (Jakarta: PT. Raja Grafindo Persada,2004).

Arifin, E. Zainal. Metode Penulisan Ilmiah. Cetakan ke-1. (Jakarta: Pustaka Mandiri, 2009).

Devita, Irma. Kiat-Kiat Cerdas, Mudah dan Bijak Mendirikan Badan Usaha. (Bandung: Kaifa, 2010).

Hadjon, Philipus M. Perlindungan Hukum Bagi Rakyat Indonesia. (Surabaya: Peradaban, 2007).

Marzuki, Peter Mahmud. Penelitian Hukum. Cetakan ke-1. (Jakarta: Kencana Prenada Media Group, 2006).

Muhammad, Abdulkadir. Hukum Pengangkutan Darat, Laut dan Udara. (Bandung: Citra Aditya Bakti, 1994).

Muhammad, Abdulkadir. Hukum Pengangkutan Niaga. (Bandung: Citra Aditya Bakti, 2013).

Nasution, Az. Hukum Perlindungan Konsumen. (Jakarta: Diadi Media, 2007).

ND, Mukti Fajar dan Yulianto Achmad. Dualisme Penelitian Hukum Normatif dan Empiris. (Yogyakarta: Pustaka Belajar, 2017).

Nurbaiti, Siti. Hukum Pengangkutan Darat (Jalan dan Kereta Api). (Jakarta: Universitas Trisakti, 2009).

Rahardjo, Satjipto. Ilmu Hukum. (Bandung: Citra Aditya Bakti, 2000).

Shidarta. Hukum Perlindungan Konsumen Indonesia. Cetakan ke-3. (Jakarta: Grasindo, 2006).

Soekanto, Soerjono. Pengantar Penelitian Hukum. Cetakan ke-3. (Jakarta: Penerbit Universitas Indonesia, 2010).

Subekti. Hukum Perjanjian. cetakan ke-19. (Jakarta: Intermasa, 2002). 
Suharnoko. Hukum Perjanjian. (Jakarta: Prenada Media, 2004).

Sutedi, Andrian. Tanggung Jawab Produk dalam Hukum Perlindungan Konsumen. Cetakan ke-1. (Bogor: Ghalia Indonesia,2008).

Widjaja, Gunawan dan Ahmad Yani. Hukum Tentang Perlindungan Konsumen. (Jakarta: PT Gramedia Pustaka Utama, 2000).

Wijaya, Andika. Aspek Hukum Bisnis Transportasi Jalan Online. (Jakarta: Sinar Grafika, 2016).

\section{B. Undang-Undang}

Indonesia, Undang-Undang Nomor 8 Tahun 1999 tentan Perlindungan Konsumen (Lembaran Negara Republik Indonesia Tahun 1999 Nomor 42, Tambahan Lembaran Negara Republik Indonesia Nomor 3821).

Indonesia, Undang-Undang Nomor 22 Tahun 2009 tentang Lalu Lintas dan Angkutan Jalan (Lembaran Negara Republik Indonesia Tahun 2009 Nomor 96, Tambahan Lembaran Negara Repubik Indonesia Nomor 5025).

\section{Internet}

“Layanan” https://www.grab.com/id/, diakses tanggal 2 Oktober 2018.

"Pengertian dan definisi online" https:// www.anakcemerlang.com/ 2015/07/pengertian-dan-definisi-online.html, diakses tanggal 19 september 2018

"Pengertian Transportasi Online", http:// www.sosialumum.com/ 2017/12/pengertian-transportasi-online-menurut-ahli.html, diakses tanggal 19 september 2018.

Trio Hamdani, "MA Cabut Permen 108, Ini Aturan Taksi Online yang Bakal Hilang", https://finance.detik.com/berita-ekonomi-bisnis/d4209472/ma-cabut-permen-108-ini-aturan-taksi-online-yangbakal-hilang, diakses tanggal 7 November 2018.

Rima Wahyunigrum, "Kronologi Penyekapan Penumpang oleh Sopir Grab Car di Tambora", https:// megapolitan.kompas.com/read /2018/04/25/17303401/kronologi-penyekapan-penumpang -olehsopir-grab-car-di-tambora, diakses tanggal 27 Juli 2018. 


\section{Kamus}

Suharso, dan Ana Retnoningsih. Kamus Besar Bahasa Indonesia. (Semarang: Widya Karya, 2017). 